\title{
An Investigation into Iranian English Major Students' Learning Styles Preferences and Their Multiple Intelligences
}

\author{
Maryam Zarei \\ Department of English, Tabriz Branch, Islamic Azad University, Tabriz, Iran
}

Zareimaryam@ymail.com

\begin{abstract}
This study was conducted to investigate the dominant perceptual learning styles and intelligences among Iranian English major students and to explore any probable relationship between each of the six types of learning styles (i.e., visual, auditory, tactile, kinesthetic, individual, and group) and the seven types of intelligences (i.e., linguistic, mathematical, spatial, bodily, musical, interpersonal, and intrapersonal). The participants in this study were 94 male and female English major students at Islamic Azad University-Tabriz Branch, Iran. Three instruments were used to obtain research data: a modified version of perceptual learning style preference questionnaire [1], a semi-structured interview, and a multiple intelligence inventory [2]. Statistical analysis and correlation of the data obtained from the questionnaires indicated that kinesthetic learning style and spatial intelligence were the most dominant among Iranian English major students. The correlation analysis also revealed significant positive relations between tactile learning style and mathematical intelligence; kinesthetic learning style and mathematical intelligence; tactile learning style and spatial intelligence; tactile learning style and bodily intelligence; and kinesthetic learning style and bodily intelligence. The findings can have practical implications for students and teachers as well as administrators, material designers, and syllabus planners.
\end{abstract}

Keywords: learning styles, multiple intelligences

\section{INTRODUCTION}

Most scholars and practitioners in the field of second language learning today agree that both the rate and the degree of success of second language learning are affected by individual learner differences, among which are learning styles and intelligences $[3,4]$. The concept of "learning styles" is used to refer to different manners that various learners use in order to approach learning. According to Brown [5], if one tried to enumerate all the learning styles that have been identified, a very long list would emerge. For example, Reid [1] has claimed that three major categories of learning styles are widely recognized and relevant to the field of foreign language learning: sensory/ perceptual learning styles, cognitive learning styles and affective/ temperament learning styles. Sensory/ perceptual learning styles, as one major category of learning styles relevant to the field of foreign language learning, have to do with the physical environment in which we learn and involve using our senses in order to perceive data. Reid [1] classifies learning styles into auditory (prefer listening to learn), visual (prefer seeing things to learn), tactile (prefer hands-on work), kinesthetic (prefer whole-body movement), group (like to work in group), and individual (like to work individually).

Learners use these learning styles as 'major' learning styles, 'minor' learning styles, or 'negligible' learning styles. 'Major' learning styles indicate that an individual could function well as a learner. 'Minor' learning style preferences indicate that an individual still can function well. 'Negative/ negligible' learning style preferences indicate that the students may have difficulty in learning. One way to solve the problem is to direct learning towards the students' preferred leaning styles [6]. According to Zhenhui [7], in all academic classrooms, no matter what the subject matter, there will be students with multiple learning styles and students with a variety of major, minor and negative learning styles. An effective means of accommodating these learning styles is for teachers to change their own styles and strategies and provide a variety of activities to meet the needs of different learning styles. Then all students will have at least some activities that appeal to them based on their learning styles, and they are more likely to be successful in these activities. 
Intelligence was once viewed strictly as the ability to perform linguistic and logical-mathematical problem solving. Traditional Intelligence Quotient (IQ) tests, based on a test called Stanford-Binet, are founded on the idea that intelligence is a single, unchanged capacity. However, traditional IQ tests, while still given to most school children, are increasingly being challenged by the Multiple Intelligence (MI) theory [8]. Gardner's theory divides human intelligence into verbal/ linguistic, logical/ mathematical, visual/ spatial, bodily/ kinesthetic, musical/ rhythmic, interpersonal, intrapersonal, naturalist and existential/ spiritual. The theory of multiple intelligences emphasizes the processes of learning rather than teaching, where teachers are challenged to notice and take into account the diverse skills, abilities and preferences that learners can exhibit in the classroom. Teachers then can present their material in ways that recognize and consider the multiple intelligences of each individual learner [9].

There is a profound distinction between these two ever more popular concepts (i.e., learning styles \& multiple intelligences), which have been put forward in order to explain the individual differences. The learning styles deal with how the individuals obtained, processed, and remembered the new and difficult information; whereas, the multiple intelligence theory explains that individuals have different multiple intelligence domains, and all of the individuals can learn if they are taught by regarding their dominant intelligence domains. Learning styles theory suggests changing the traditional instructional methods to benefit from the individuals' learning styles, and features the process by emphasizing how to perform the instruction. Whereas, the multiple intelligences theory emphasizes what to be instructed, that is, the product [10].

To be successful in educating the diverse population of learners, teachers need to be aware of their students' learning styles and multiple intelligences [11]. Prashnig [12] mentioned that teachers need to know about both concepts, and should assess their students' learning styles as soon as possible to help them develop their different intelligence factors in a way which is conducive to their individual learning styles. When these important aspects are understood and acted upon, learning becomes more enjoyable for students who struggle in traditional classrooms. Accordingly, this study aims to investigate the mostly preferred learning styles and intelligence types in an Iranian EFL context, and to explore any probable relationship between each of the learning styles and intelligence scores. Regarding these purposes, the following research questions were formulated:

1. What preferences do Iranian English major students have for particular perceptual learning styles?

2. What type(s) of intelligence(s) is/are mostly exhibited by Iranian English major students?

3. Is there a significant relationship between the perceptual learning styles scores and multiple intelligences scores of Iranian English major students?

\section{METHOD}

\subsection{Participants}

Ninety-four English as a foreign language (EFL) sophomores at Islamic Azad University-Tabriz Branch, Iran, participated in this study. They all majored in English, but their mother tongue was either Azari Turkish or Persian. The population was both male and female and within the age range of 19 to 30 . The whole data were collected by the researcher over a span of 10 weeks.

\subsection{Instruments}

To handle this study, the researcher used three different instruments. The first instrument was the Persian translation of a perceptual learning style preference questionnaire (PLSPQ), developed by Reid [1] particularly for learners of foreign language. The questionnaire was translated into Persian by the researcher to facilitate the data collection process and remove any probable language barriers. The initial number of items in the questionnaire was 30 which were later reduced to 26 statements for six learning style preferences: visual, auditory, tactile, kinesthetic, group learning, and individual learning. Subjects were expected to indicate how much they agreed with each item on a scale from 1 to 5 when they learned English. Each number noted certain measurement such as: (5) strongly agree, (4) agree, (3) undecided, (2) disagree, and (1) strongly disagree. The 26-item questionnaire was scored by assigning points to each Likert-type scale response, with the highest total score indicating the individual's learning style. 
Getting the idea from DeCapua and Wintergerst [13] that using more than one method for gathering data allows researcher greater opportunities to gain better insights into what they are researching, the researcher applied a 'semi-structured interview' to see whether there were any differences between the preferred styles of the learners chosen in the questionnaire and their overall idea about the learning styles. The interviewees were selected from the subjects who had completed the perceptual learning style preference questionnaire (PLSPQ) and the general format of the interview with some revisions was adapted from $\mathrm{Wu}[14]$.

Finally, the Persian translation of a multiple intelligences (MI) inventory, prepared by Christison [2] and translated by the researcher into Persian, was used in the study. The inventory consisted of a three-point Likert-type scale with 42 items measuring types of intelligences. Assessing seven intelligences, the inventory had six statements for each specific intelligence type (i.e., verballinguistic, logical- mathematical, spatial-visual, bodily-kinesthetic, musical-rhythmic, interpersonal and intrapersonal intelligence). The scales of the questionnaire were from 0 to 2 representing, disagree, somewhere in between, and strongly agree, respectively.

\subsection{Procedure}

The first stage of the study started with administrating the Persian translation of perceptual learning style preference questionnaire (PLSPQ), which had been adapted from Reid [1]. The researcher used the PLSPQ to identify the ways in which learners learn best and prefer to learn. It took about 15 minutes for the students to answer the questionnaire items and then the sheets were collected.

To ensure that the items of the perceptual learning style preferences in the questionnaire (PLSPQ) were not chosen by chance, the researcher employed 24 semi-structured interviews with participants chosen randomly from the persons who had completed the learning style questionnaire. In fact, in this study, six groups were interviewed. Each of the six groups consisted of four participants: the first group had the highest score for visual learning style (LS); the second group had the highest score for auditory LS; the third one had the highest score for tactile LS; the fourth had the highest score for kinesthetic LS; the fifth had the highest score for individual LS; and the last one had the highest score for group LS. The purpose of this grouping was to get equal number of students from each of the six learning styles for the interview phase. Each interview lasted for about 15 to 20 minutes and was recorded using an MP3 player with the consent of participants. The interviews were conducted in Persian, the official language of both the participants and the interviewers. These interviews were conducted by the researcher who met individually with each volunteer at a mutually convenient time.

Finally, the researcher used the Persian translation of a MI inventory adapted from Christison [2] to determine the subjects' multiple intelligences scores. The instrument included 42 three-point Likerttype questions that covered seven areas of abilities, interests, skills and activities. Respondents were asked to read each item and select what they perceived as the best answer at that point in time in their life.

\subsection{Data Analysis}

In the stage of data analysis, the researcher employed descriptive statistics (e.g., mean \& standard deviation) to attain the answers to the research questions 1 and 2; furthermore, to respond the research question 3, they applied the correlation analysis (i.e., Pearson product moment correlation) to assess the relationship between the learning styles and the intelligences.

\section{RESUlTS}

\subsection{The Results of the Learning Style Preference Questionnaire}

Table 1 indicates the descriptive results of the perceptual learning style preference questionnaire (PLSPQ) used in the study:

Table1. Descriptive Statistics for the Perceptual Learning Style Preference Questionnaire

\begin{tabular}{|c|c|c|c|c|c|c|}
\hline & visual & auditory & tactile & kinesthetic & individual & group \\
\hline $\mathrm{N}$ & 94 & 94 & 94 & 94 & 94 & 94 \\
\hline Mean & 15.4468 & 11.6915 & 18.4149 & 15.9894 & 16.7660 & 18.2447 \\
\hline Std. Deviation & 2.65839 & 1.87242 & 3.31309 & 2.12256 & 4.62677 & 4.33462 \\
\hline
\end{tabular}


According to the percentages obtained for each learning style (LS), the mostly preferred learning style was kinesthetic LS (80\%), followed by auditory LS (78\%), visual LS (77\%), tactile LS (74\%), group LS (73\%) and individual LS (67\%). The frequencies obtained indicate that each participant uses a combination of different learning modalities to learn effectively; however, some of these learning modalities are more frequently applied by them. Therefore, it can be said that Iranian English major students have preferences for particular perceptual learning styles.

\subsection{The Results of the Multiple Intelligences Inventory}

The following table presents the description of the Multiple Intelligences (MI) inventory used in the study:

Table2. Descriptive Statistics for the Multiple Intelligences Inventory

\begin{tabular}{|c|c|c|c|c|c|c|c|}
\hline & linguistic & mathematical & spatial & bodily & musical & interpersonal & intrapersonal \\
\hline $\mathrm{N}$ & 94 & 94 & 94 & 94 & 94 & 94 & 94 \\
\hline Mean & 7.010 & 6.691 & 8.766 & 5.861 & 4.957 & 7.861 & 5.436 \\
\hline $\begin{array}{c}\text { Std. } \\
\text { Deviation }\end{array}$ & 2.013 & 2.782 & 2.147 & 2.495 & 2.543 & 2.168 & 2.153 \\
\hline
\end{tabular}

The analysis revealed that spatial intelligence $(M=8.76)$ was the leading intelligence among the students who participated in the study. The other dominant intelligence types were interpersonal intelligence ( $M=7.86)$, linguistic intelligence $(M=7.01)$, and mathematical intelligence $(M=6.69)$. They were followed by less common intelligences, namely bodily intelligence $(\mathrm{M}=5.86)$, intrapersonal intelligence $(\mathrm{M}=5.43)$, and musical intelligence $(\mathrm{M}=4.95)$.

\subsection{The Results of the Pearson Correlations}

Table 3 demonstrates the results of Pearson's correlation analysis for the learning styles and the intelligence types:

Table3. Pearson Correlations between Learning Styles and Intelligence Types

\begin{tabular}{|c|c|c|c|c|c|c|c|}
\hline & & visual & auditory & tactile & kinesthetic & individual & group \\
\hline Linguistic & $\begin{array}{c}\text { Pearson } \\
\text { Correlation }\end{array}$ & .005 & .138 & .196 & 121. & 125. & $121-$. \\
& Sig. (2-tailed) & .961 & .185 & .058 & .246 & .230 & .240 \\
\hline & $\mathrm{N}$ & 94 & 94 & 94 & 94 & 94 & 94 \\
\hline Mathematical & $\begin{array}{c}\text { Pearson } \\
\text { Correlation }\end{array}$ & -.109 & .052 & $.273\left(^{* *}\right)$ & $.227\left(^{*}\right)$ & .063 & -.005 \\
\hline & Sig. (2-tailed) & .295 & .621 & .008 & .028 & .548 & .960 \\
\hline & $\mathrm{N}$ & 94 & 94 & 94 & 94 & 94 & 94 \\
\hline Spatial & $\begin{array}{c}\text { Pearson } \\
\text { Correlation }\end{array}$ & -.036 & .051 & $.281\left(^{* *}\right)$ & .146 & -.058 & .032 \\
\hline & Sig. (2-tailed) & .730 & .623 & .006 & .161 & .582 & .762 \\
\hline & $\mathrm{N}$ & 94 & 94 & 94 & 94 & 94 & 94 \\
\hline Bodily & $\begin{array}{c}\text { Pearson } \\
\text { Correlation }\end{array}$ & .056 & .051 & $.224\left(^{*}\right)$ & $.245\left(^{*}\right)$ & -.046 & .147 \\
\hline & Sig. (2-tailed) & .589 & .628 & .030 & .017 & .662 & .157 \\
\hline & $\mathrm{N}$ & 94 & 94 & 94 & 94 & 94 & 94 \\
\hline Musical & $\begin{array}{c}\text { Pearson } \\
\text { Correlation }\end{array}$ & -.072 & -.012 & .045 & -.102 & .061 & -.119 \\
\hline & Sig. (2-tailed) & .491 & .910 & .663 & .330 & .557 & .253 \\
\hline & $\mathrm{N}$ & 94 & 94 & 94 & 94 & 94 & 94 \\
\hline Interpersonal & $\begin{array}{c}\text { Pearson } \\
\text { Correlation }\end{array}$ & -.151 & .079 & .065 & .133 & -.179 & .113 \\
& Sig. (2-tailed) & .145 & .447 & .534 & .202 & .084 & .276 \\
\hline & $\mathrm{N}$ & 94 & 94 & 94 & 94 & 94 & 94 \\
\hline & $\begin{array}{c}\text { Pearson } \\
\text { Correlation }\end{array}$ & -.029 & -.060 & .068 & .079 & .023 & -.050 \\
\hline & Sig. (2-tailed) & .783 & .568 & .516 & .451 & .824 & .635 \\
\hline & $\mathrm{N}$ & 94 & 94 & 94 & 94 & 94 & 94 \\
\hline
\end{tabular}

In table 3, Pearson product moment correlations reveal that there are some significant relationships between learning styles of Iranian English major students and their intelligence types. Results show 
that there are low positive relationships between tactile learning style and mathematical intelligence $(\mathrm{r}=0.27, \mathrm{p}=0.008<0.05)$; tactile learning style and spatial intelligence $(\mathrm{r}=0.28, \mathrm{p}=$ $0.006<0.05)$; tactile learning style and bodily intelligence $(\mathrm{r}=0.22, \mathrm{p}=0.030<0.05)$; kinesthetic learning style and mathematical intelligence $(\mathrm{r}=0.22, \mathrm{p}=0.028<0.05)$; and kinesthetic learning style and bodily intelligence $(r=0.24, p=0.017<0.05)$. However, statistically significant relationships were not discovered between tactile learning style, kinesthetic learning style and the other intelligence types (e.g., linguistic intelligence), nor were relationships found between visual learning style, auditory learning style, individual learning style, group learning style and intelligence types.

\section{Discussion AND CONCLUSION}

The present study set out to investigate the dominant perceptual learning styles and intelligences which were preferred by Iranian English major students and further examined the relationship between each of the perceptual learning styles and intelligence types. The descriptive statistics revealed that the mostly preferred learning style (LS) was kinesthetic, followed by auditory LS, visual LS, tactile LS, group LS and individual LS. The finding is compatible with the research findings of Mulalic, Mohd Shah, and Ahmad [15]. Mulalic et al. [15] conducted a research in the Department of Language and Communication in National Tenaga University in Malaysia to determine the learning styles of the students. They found out that students' major preferred learning style was kinesthetic. The result of this study contradicts the result obtained by Hsu [16]. Hsu [16] investigated Taiwanese elementary school students' preferred learning styles. The sample was composed of third to sixth grade students from three different schools in Taichung. Results indicated that Taiwanese elementary school students had a strong preference for group learning style.

The research findings emerging from the descriptive statistics for the second research question indicated that spatial intelligence $(M=8.76)$ was the leading intelligence and musical intelligence $(\mathrm{M}=4.95)$ was the least common intelligence type among the students who participated in the study. These results contradict the research findings of Wang [17] and Saricaoglu and Arikan [18]. Wang [17] found out that bodily-kinesthetic intelligence was the most superior intelligence among the elementary students in Kaohsiung city in China. With the aim of finding out about the leading intelligence among the students, Saricaoglu and Arikan [18] conducted a study with preparatory class students attending English courses at Erciyes University's School of Foreign Languages in Turkey. They reported that Turkish learners of English had stronger preference for logical mathematical intelligence. The result of the current study is in line with Saricaoglu and Arikan's [18] study as well, in that in both studies, the students were found to be weaker in musical intelligence.

The present study also looked at the relationship between each of the language learning styles and the multiple intelligences scores. The correlation analysis of the results indicated that there were positive relations between tactile learning style and mathematical intelligence; kinesthetic learning style and mathematical intelligence; tactile learning style and spatial intelligence; tactile learning style and bodily intelligence; and kinesthetic learning style and bodily intelligence. These findings are in contrast with the results of the study conducted by Tekiner [19]. She investigated the relationships between preferences of multiple intelligences and perceptual and social learning styles among university students in Turkey. The results of her study showed that there were positive relations between interpersonal intelligence and group learning style; linguistic intelligence and individual learning style; logical mathematical intelligence and individual learning style; intrapersonal intelligence and individual learning style; and interpersonal intelligence and kinesthetic learning style; in addition, in her study, negative relations were found between interpersonal intelligence and individual learning style; musical intelligence and individual learning style; and bodily-kinesthetic intelligence and tactile learning style.

Differences between the results of this study conducted by the present researcher in an English as a foreign language (EFL) context and those obtained by other researcher in other EFL or English as a second language (ESL) contexts may be attributed to EFL and ESL students' cultural differences or the ways each of the researcher conducted his/her study. Moreover, the other variable which may have differentiated the results of this study with those of some other studies might be the participants' educational level. That is, students from different levels of education may differ from one another in their learning styles and intelligence preferences. 
The results obtained indicate that each participant uses a combination of different learning modalities to learn effectively. We also come to conclude the idea articulated by Nolen [20] that individuals have each intelligence to a certain level, but as a result of the exposure to specific social and instructional conditions designed for a certain intelligence type, this intelligence type develops to a higher level in the individual. Hence, teachers should try to develop and strengthen weaker learning styles and intelligences through easier tasks and drills and by planning and delivering a series of instructional events in multiple modes.

\section{REFERENCES}

[1] Reid J. M., Learning styles in the ESL/ EFL classroom, Boston: Heinle and Heinle, 63 (1995).

[2] Christison M. A., Applying multiple intelligence theory in the foreign language classroom, MEXTESOL Journal, 19 (3), 27-43 (1996).

[3] Ellis R., Understanding second language acquisition, Oxford: Oxford University Press, 113 (1985).

[4] Williams M. and Burden R. L., Psychology for language teachers, Cambridge: Cambridge University Press, 45 (1997).

[5] Brown H. D., Principles of language learning and teaching (4th ed.), San Francisco: Longman, 78 (2000).

[6] Reid J. M., The learning style preferences of ESL students, TESOL Quarterly, 21 (1), 87-110 (1987).

[7] Zhenhui R., Matching teaching styles with learning styles in East Asian contexts, TESL Journal, 7 (7), 33-40 (2001).

[8] Brown H. D., Teaching by principles: An interactive approach to language pedagogy (2nd ed.), San Francisco: Longman, 98 (2001).

[9] Gardner H., The development and education of the mind, London: Routledge, 31(2006).

[10] Denig S. J., Multiple intelligences and learning styles: Two complementary dimensions, Teachers College Record, 106(1), 96-111 (2004).

[11] Finley R., The relationship between learning styles/ multiple intelligences and academic achievement of high school students, April 15, from www. highbeam.com/doc/1G159210397.html. (1999).

[12] Prashnig B., Learning styles vs. multiple intelligences, February 11, from www.creativelearningcentre.com/.../Article-Learning-Styles-vs- html. (2005).

[13] DeCapua A., and Wintergerst A. C., Assessing and validating a learning styles instrument, System, 33, 1-16 (2005).

[14] Wu M., Language learning strategy use of Chinese ESL learners of Hong Kong: Findings from a qualitative study, Journal of Foreign Language Teaching, 5, 68-83(2008).

[15] Mulalic A., Mohd Shah P. and Ahmad F., Perceptual learning styles of ESL students, Journal of Social Sciences, 7 (3), 101-113 (2009).

[16] Hsu Y. L., Elementary school EFL students' learning style preferences and their relationship with the students' English learning achievement, December 1, from ethesys.lib.pu.edu.tw/ETDdb/ETD-search/view_etd?URN=etd... (2006).

[17] Wang S. F., A study of the relationship between learning style and multiple intelligences in elementary students, February 5, from 140.127.82.162/ ETD-db/ETD-search/view_etd URN= etd. (2003).

[18] Saricaoglu A. and Arikan A., A Study of multiple intelligences, foreign language success and some selected variables, International Journal of Educational researcher, 1(1), 22-36 (2009).

[19] Tekiner A., The relationship between perceptual and social learning styles and multiple intelligences and their effects on English proficiency of Turkish young adults learning English as a foreign language, February 5, from www. ii.metu.edu.tr/.../relationship-between-perceptualand-social-learning-styles-and-multiple-intelligences-a-0. (2005).

[20] Nolen J. L., Multiple intelligences in the classroom, February 13, from findarticles.com/p/ articles/mi_qa3673/is.../ai_n29032699 (2003). 
An Investigation into Iranian English Major Students' Learning Styles Preferences and Their Multiple Intelligences

\section{AUTHORS' BIOGRAPHY}

Maryam Zarei, is currently a Ph.D. candidate in English Language Teaching at Islamic Azad University-Tabriz Branch, Iran. She has experience of teaching English in Ministry of Education, and now she is an English instructor at Islamic Azad University-Astara Branch, Iran. She has published and presented papers in national and international journals and conferences. Her research interests are individual differences, lesson plans, and task-based research. 